Запропоновано підхід до обтрунтування закономірностей зміни показників використання молочних цехів на території громад за різних їх параметрів та із врахуванням мінливих виробничих умов. Цей підхід базуеться на проведені експериментальних дослідженнях складових виробничих умов, враховує ïx особливості для кожної окремої громади $i$ передбачає моделювання виконання робіт $y$ переробних цехах.

На підставі прогнозування добових обсягів надходження на переробку молока від господарств громад впродовж календарного року встановлено, що існує два періоди - інтенсивний (з 119 по 301 доби календарного року) та неінтенсивний (з 1 по 118 та з 302 по 365 добу календарного року). У інтенсивний період переробки молока слід організовувати роботу у дві зміни, а у неінтенсивний період у одну зміну. Встановлено, що добові обсяги переробки молока описуються законами розподілу Вейбулла, а їх статистичні характеристики впродовж інтенсивного та неінтенсивного періодів відповідно становлять: коефічієнт варіачії - 0,65 та 0,62; параметр форми 1,56 та 1,64. При иьому, довірчий інтервал знаходиться в межах 509...6995 та 46...634 л.

На прикладі виробничих умов Бродівського району Львівської області (Україна) проведено дослідження щодо обтрунтування закономірностей зміни показників використання молочних цехів на території громад за різних їx параметрів та із врахуванням мінливих виробничих умов. Встановлено, що зі зростанням продуктивністі молочних цехів від 0,5 до $20 \mathrm{~m} /$ добу пропориійно знижуеться питоме споживання електроенергії від 116 до $10 \mathrm{\kappa Bm} /$ тону, питоме споживання води від 10 до 0,3 $\mathrm{m}^{3} /$ тону та питома потреба $(\mathrm{Nu})$ y людській праці від 0 до 0,3 осіб/тону за виробництва різних видів молочних продуктів.

Досліджені мінливі виробничі умови та визначені тенденції зміни показників використання молочних цехів на території громад лежать в основі визначення вартісних показників. Результати проведених досліджень будуть корисними під час ідентифікаиії конфігурації проектів створення цехів виробництва молочних продуктів на території громад

Ключові слова: функціонування, цех, переробка молока, ефективність, планування, моделювання, стохастичність, виробничі умови
UDC 005:658.631.3

DOI: $10.15587 / 1729-4061.2019 .184508$

\title{
ESTABLISHING PATTERNS OF CHANGE IN THE INDICATORS OF USING MILK PROCESSING SHOPS AT A COMMUNITY TERRITORY
}

\begin{abstract}
A. Try h u b a
Doctor of Technical Sciences, Professor, Head of Department Department of Information Systems and Technologies*

M. Rud y net s

$\mathrm{PhD}$, Associate Professor

Department of Civil Security**

E-mail: RudynetsMykola@lutsk-ntu.com.ua

N. Pavlikha

Doctor of Economic Sciences, Professor, Vice-rector $* * *$

I. Try h u ba

$\mathrm{PhD}$, Associate Professor

Department of Genetics, Breeding and Plant Protection*
\end{abstract}

I. K y t s y u k

$\mathrm{PhD}$, Associate Professor

Department of International Economic Relations and Project Management***

O. Korneliuk

$\mathrm{PhD}$, Senior Lecturer

Department of International Economic Relations and Project Management $* * *$

V. Fedorchuk-Moroz

$\mathrm{PhD}$, Associate Professor Department of Civil Security**

I. A ndrosh ch u k

$\mathrm{PhD}$, Associate Professor Department of Civil Security**

I. Skorokhod

$\mathrm{PhD}$, Associate Professor Department of International Economic Relations and Project Management***

D. S e le z nov

$\mathrm{PhD}$, Senior Lecturer Department of Industry Engineering and Forestry**

* Lviv National Agrarian University

V. Velykoho str., 1, Dublyany, Ukraine, 80381

**Lutsk National Technical University

Lvivska str., 75, Lutsk, Ukraine, 43018

***Lesya Ukrainka Eastern European National University

Voli ave., 13, Lutsk, Ukraine, 43025

\section{Introduction}

The food security problem remains unresolved in the world today. The problem became more important due to growing demands of the World Trade Organization for food quality, because farms of individual communities produce the major portion of raw milk and they do not have their own processing shops. Large dairy plants, which are monopolists in this field, process dairy raw material. Dairy plants dictate price policy and it becomes unprofitable for small farms to produce raw milk. Duration of a period from milk production to its processing increases, which reduces quality of dairy 
products. The situation does not meet the requirements of the EU law. Milk belongs to perishable products and it has specific requirements for its processing.

It is necessary to implement projects for creation of milk processing shops (MPS) at community territories to solve the existing problem. The government developed a series of programs, which promote development of communities and creation of manufacturing facilities in their territories. At the same time, MPS remain out of attention, but their product configuration has a significant impact on both quality of dairy production and its cost.

It is necessary to identify characteristics of configuration objects of the specified projects and their products for the effective implementation of MPS in territories of individual administrative communities. We must use specific methods and models to do this. In particular, the toolkit for identification of characteristics of MPS product configuration objects in territories of individual administrative communities should take into account features of a production component of the project environment. The features include presence and parameters of dairy farms, their territorial location, a state of a road network between them, etc. Seasonality of milk production plays an important role. The mentioned features of the production component of the project environment determine operation modes of a processing shop and characteristics of equipment for milk processing. The features are specific in each community and have a significant impact on performance of milk processing shops. Also, the production component of the project environment influences operating modes of processing shops during a calendar year.

Effective implementation of MPS is impossible without resolution of the task of identification of their products taking into account the fact that individual communities have their own specific features of a production component of the project environment. Quality identification of MPS products requires justification of regularities of changes in the use of milk processing shops at community territories according to their different parameters and taking into consideration changing production conditions.

\section{Literature review and problem statement}

Authors of study [1] propose an approach to identification of characteristics of objects of configuration of project products. Works [2-5] are about improvement of efficiency of using of project configuration objects by different criteria (cost, environmental impact, etc.). Works [6-8] take into account features of the use of configuration objects in projects. However, it is impossible to use the results of studies obtained in [6-8] to establish regularities of changes in the use of milk processing shops in territories of individual administrative communities, because there are no criteria for the quality of production of dairy products and time for their production. These criteria are specific for the study on functioning of milk processing shops, which produce perishable foods including dairy products.

Authors of papers [9-11] suggest to model operation of system configuration objects to determine indicators of their use. However, the above methods and models use deterministic indicators of the usage of system configuration objects as their basis. It is impossible to use the results of the studies on functioning of milk processing shops obtained in [9-11], because they do not take into account variable volumes of raw materials coming to processing shops during a calendar year and conditions and features of performance of works in production of dairy products.

Works [12-14] suggest substantiating a need for system configuration objects taking into account variable loading volumes, and works [15-17] - taking into account their risk. However, it is impossible to use the results obtained in [12-17] to determine trends in changes in the use of milk processing shops in territories of individual administrative communities, because authors do not take into account the specific characteristics of production conditions. In particular, they do not take into account features of the production component of functioning of milk processing shops, which is specific in each of the territory communities. In addition, they do not take into account seasonality of milk production and, accordingly, a volume of milk processing. All the above affects the efficiency of operation of milk processing shops $[18,19]$ and quality of dairy products produced significantly [20].

One knows that adequate forecasting of characteristics of a production component of functioning of milk processing shops is possible through on their modeling only [20,22]. However, as regards functioning of milk processing shops, it is necessary to carry out specific studies for each of community territory where we plan to place a milk processing shop [21]. It is not possible to determine trends in changes in the use of milk processing shops adequately and to substantiate the effective configuration of their projects without taking into account specific production conditions of individual communities and without taking into account seasonality of milk production.

One should note that there are scientific works $[13,16]$, which forecast production conditions of milk processing systems partially. However, authors of scientific works [13, 16] take into account receipt of milk for its processing from large farms. They do not forecast conditions of milk production by farms in a community adequately. In addition, they do not provide for modeling of the use of milk processing shops, taking into consideration seasonality of milk production, which makes it impossible to justify trends of changes in the use of milk processing shops at a community territory adequately.

Researchers paid enough attention to the solution of the task of identification of characteristics of project product configuration objects in different areas. However, authors of scientific papers do not take into account features of MPS fully. That is why we need an appropriate scientific research. In particular, quality identification of MPS products requires justification of regularities of changes in indicators of the use of milk processing shops at community territories at different parameters and taking into account changing production conditions.

\section{The aim and objectives of the study}

The objective of this study is the identification of trends in changes in indicators of the use of milk processing shops at a community territory under different parameters and taking into account changing production conditions, which underlie the formation of a knowledge base for supporting making of management decisions about planning of configuration of the specified milk processing shops. 
We set the following tasks to achieve the objective:

- substantiation of stages and features of forecasting of functional indicators of milk processing shops at a community territory;

- investigation of an influence of parameters of community milk processing shops on indicators of their use taking into account changing production conditions.

\section{Stages and features in forecasting functional indicators of milk processing shops at community territories}

Forecasting of the use of milk processing shops at a community territory consists of five stages (Fig. 1).

\begin{tabular}{|l|l|}
\hline & $\begin{array}{l}\text { Formation of a database on the availability of modular milk processing } \\
\text { shops in the market and their characteristics }\end{array}$ \\
\hline & $\begin{array}{l}\text { Analysis of production conditions of milk processing at a community } \\
\text { territory }\end{array}$ \\
\hline & $\begin{array}{l}\text { Forecasting of trends in the change in volumes of milk for processing } \\
\text { within a calendar year }\end{array}$ \\
\hline community
\end{tabular}

\section{Fig. 1. Stages in forecasting indicators of using milk} processing shops at a community territory

Stage 1. Construction of a database on the availability of modular milk processing shops in the market and their characteristics. The formation of a database on the availability of modular milk processing shops on the market provides for the analysis of presence of modular milk processing shops of different productivity for processing of milk on the domestic market for a given dairy production technology. It is necessary to fill in the forms for each of the shops of a given productivity. Forms contain data on characteristics of their technical equipment (Table 1).

The form of characteristics of technical equipment of modular shops for processing of milk

\begin{tabular}{|c|c|c|c|c|c|c|c|}
\hline \multirow{2}{*}{ Indicator } & \multirow{2}{*}{$\begin{array}{c}\text { Measure- } \\
\text { ment unit }\end{array}$} & \multicolumn{7}{|c|}{ Productivity, tons/day } \\
\cline { 3 - 8 } & 0.5 & 1 & 3 & 5 & 10 & 20 \\
\hline $\begin{array}{c}\text { Installed } \\
\text { power }\end{array}$ & $\mathrm{kW}$ & 57 & 85 & 163 & 222 & 439 & 638 \\
\hline Water loss & $\mathrm{m}^{3} /$ day & 5 & 6 & 6.5 & 7 & 8 & 20 \\
\hline $\begin{array}{c}\text { Drainage } \\
\text { rate }\end{array}$ & $\mathrm{m}^{3} / \mathrm{h}$ & 3.5 & 3.5 & 3.5 & 3.5 & 5.5 & 5.5 \\
\hline $\begin{array}{c}\text { Human } \\
\text { labor needs }\end{array}$ & persons & 1 & 1 & 2 & 3 & 5 & 6 \\
\hline Cost & $\begin{array}{c}\text { UAH, } \\
\text { thousand }\end{array}$ & $2,056.63$ & $2,123.6$ & $5,982.06$ & $7,449.4$ & 12,989 & 17,744 \\
\hline
\end{tabular}

It is possible to analyze the availability of technical equipment of modular shops for processing of milk on the market and technological features of their use based on the completed form (Table 1). Dairy production technologies use types of obtained dairy products and performance of separate operations (machine, automated, combined) as a basis [22-24]. A choice of modular milk processing shops occurs according to the chosen technology.
Stage 2. Analysis of production conditions of milk processing at a community territory. Justification of presence and territorial location of milk producers in individual communities occurs based on the analysis of reporting documentation of these communities. We can express the volume $\left(Q_{d n}\right)$ of milk supply from each of individual producers of milk at a community territory on the $t$-th day of a season of its processing by formula:

$$
Q_{d n}=\sum_{x=1}^{N_{s n}} Q_{d x j}
$$

where $\left(Q_{d x j}\right)$ is the volume of milk production of $x$-th farm, which sells it to the $n$-th shop on the $j$-th day of a season of its processing, t; $N_{s n}$ is the number of farms that sell milk to the $n$-th processing shop, units.

Characteristics of the organizational component of milk processing at a community territory include a mode of work execution (a number of changes in the operation of milk processing shops), which is variable during a separate calendar year. The cause of its change (adaptation) is a temporary change in a volume of milk processing during a calendar year. We can forecast the change in dependence on the amount of milk supply for processing.

Stage 3. Forecasting trends of change in the volumes of milk for processing within a calendar year. Daily production of milk in $x$-th community, which forms a flow of orders for implementation of milk processing works on the specified technical equipment of modular shops, is variable. It has the following characteristics: a number of dairy herds in a community $\left(n_{k}\right)$, their productivity $\left(q_{k}\right)$ and age $\left(v_{k}\right)$, a day, when milk is produced within the period of lactation of cows $\left(\tau_{i}\right)$, a $\operatorname{diet}(\theta)$ and conditions of keeping of cows $(\omega)$ :

$$
Q_{d x j}=f\left(n_{k}, q_{k}, v_{k}, \tau_{i}, \theta, \omega\right) .
$$

Considering $v_{k}, \tau_{i}, \theta$, and $\omega$ are probable quantities, $Q_{d x j}$ will also be probable. Therefore, quantitative value of forecasting of $Q_{d x j}$ requires application of statistical methods.

Table 1 We can use analytical-experimental method based on statistical modeling of the value production to forecast $Q_{d x j}$ quantitative value. The application of the method makes possible to justify quantitatively a variable volume of milk received for processing not only totally from all farms at a community territory, but also to forecast a variable volume of milk received for processing from each farm. This, together with the territorial location of farms, has an impact on a cost of milk processing resources and a cost of milk products obtained after milk processing.

The feature of forecasting of a volume $\left(Q_{d x j}\right)$ of milk received for processing on a single day is that the volume is variable and depends on the lactation period of cows. It lasts from 265 to 435 days (depending on a breed, age and productivity of cows, etc.). The volume is shifted relatively to a calendar year for individual cows and milk production goes throughout the entire calendar year. However, the major portion of milk production volumes falls on summer months. Therefore, technical equipment of a processing shop works intensively in summer months.

The total volume $Q_{d}^{k}$ of milk production on the $j$-th day is:

$$
Q_{d}^{k}=\sum_{j=1}^{n} Q_{d j}^{k} \cdot z_{j} \cdot k_{x}
$$


where $z_{j}$ is the number of milking of cows per day; $k$ is a coefficient, which takes into account the proportion of raw milk left by producing farms for its own use; $k_{x}$ is the settlement at a territorial community.

Step 4. Modeling of functioning of milk processing shops at a community territory. The modeling of functioning of milk processing shops at a community territory occurs based on implementation of separate daily cycles of their functioning, the total duration of which is equal to the duration of a calendar year $\left(t_{c}=365\right.$ days). It is necessary to determine forecasting functional parameters of milk processing shops for each of the cycles, such as a daily volume $\left(Q_{d v}\right)$ of processed milk; daily complexity $\left(\theta_{d v}\right)$ of milk processing; a daily volume $\left(P_{e}\right)$ of consumed electricity; a daily volume $\left(q_{w}\right)$ of water consumed.

Having the quantitative value of the intensity $\left(I_{d j}\right)$ of milk production on $j$-th day of a calendar year and given the value of the daily productivity $\left(W_{c d}\right)$ of a milk processing shop, we can determine the forecasting volume $\left(Q_{d v j}\right)$ of milk supply for processing from by a milk processing shop on $j$-th day of a calendar year, by formula

$$
Q_{d v j}=W_{c d} \cdot I_{d j}
$$

We can determine the daily complexity $\left(\theta_{d v}\right)$ of milk processing from formula

$$
\theta_{d v}=N_{u} \cdot t_{\text {zes }} \cdot n_{\text {nwes }} \cdot k_{s t},
$$

where $N_{u}$ is the number of performers, persons; $t_{\text {wes }}$ is the duration of a work shift, h; $n_{\text {nwe }}$ is the number of work shifts at a milk processing shop, units; $k_{s t}$ is the coefficient of time use factor of a shift.

One can determine the daily volume of electricity consumption $\left(P_{e}\right)$ from formula

$$
P_{e}=P_{c} \cdot t_{n j} \cdot k_{e j},
$$

where $P_{c}$ is the total installed power of electricity consumers at a milk processing shop, $\mathrm{kW} ; t_{n j}$ is the duration of milk processing shop operation on the $j$-th day of a calendar year, h; $k_{e j}$ is the coefficient of use of electricity by consumers at a milk processing shop on the $j$-th day of a calendar year.

One can determine the daily volume of water consumption $\left(q_{w}\right)$ from formula

$$
q_{w}=q_{w}^{n} \cdot k_{s t},
$$

where $q_{w}^{n}$ is specific water consumption, $\mathrm{m}^{3} /$ day; $k_{s t}$ is the coefficient of water use during the change.

One can determine total annual values having quantitative values of the forecasted daily functional indicators of milk processing shops at a community territory.

Stage 5.Justification of regularities of changes in indicators of the use of milk processing shops at a community territory. Based on the obtained quantitative values of the forecasted total annual indicators of functioning of milk processing shops, one can build their dependences on changes in the productivity of shops. The correlation-regression analysis of the dependences makes it possible to substantiate their equations and correlation coefficients, which testifies to the probability of the obtained regularities of changes in the use of milk processing shops at a community territory at their different parameters and taking into account changing production conditions.

\section{Results of studying the influence of parameters of milk processing shops on indicators of their use taking into account changing production conditions}

We carried out studies on the functioning of milk processing shops at a community territory according to the above stages (Fig. 1). First of all, we carried out an analysis of milk processing equipment and shops available on the market, which meet the current EU requirements for the quality of dairy production. The analysis of milk processing shops manufactured in the world shows that they are multivariate. Shops differ in both a technology of milk processing and a type of obtained milk products, their packaging, a use of human labor, availability and planning of production and auxiliary premises, features of technological processes and technical equipment for their implementation. According to the criteria of cost and quality, we selected modular miniplants manufactured by CJSC "COLAX-M" for further research. The main advantage of "COLAX" modular dairy mini-plants (shops) is that they are ready-to-use complexes for milk processing. In addition, the company manufactures modular mini-plants for milk processing with a wide range of productivity (from 0.5 to $20 \mathrm{t}$ /day).

Modular "COLAX" milk mini-plant contains a set of equipment for storage and processing of milk mounted in a single line. Each mini-plant has systems of cold and hot water supply, power supply, drainage, heating, ventilation, and air conditioning. "COLAX" mini-plant is able to perform the following operations:

- acceptance, purification, cooling and storage of milk;

- pouring and packing of milk into any packages (polyethylene or Pure-Pack);

- obtaining of any dairy and sour milk products;

- restoration of milk powder;

- storage of finished products in refrigerators of shops;

- provision of living conditions for staff.

Table 2 shows characteristics of dairy products produced by "COLAX" modular dairy mini-plants (shops), depending on their productivity.

Table 2

Characteristics of dairy products produced by "COLAX" modular dairy mini-plants (shops)

\begin{tabular}{|c|c|c|c|c|c|c|}
\hline \multirow{2}{*}{ Type of a dairy product } & \multicolumn{6}{|c|}{ Productivity of a milk processing shop, } \\
\cline { 2 - 7 } & 0.5 & 1 & 3 & 5 & 10 & 20 \\
\hline Pasteurized milk (3.7 \%) & 0.265 & 0.431 & 1.294 & 2.157 & 5.914 & 12.628 \\
\hline $\begin{array}{c}\text { Sour cream or dairy } \\
\text { cream (20 \%) }\end{array}$ & 0.035 & 0.069 & 0.136 & 0.243 & 0.4 & 1 \\
\hline $\begin{array}{c}\text { Cultured milk beverage } \\
\text { kefir (2.5\%) }\end{array}$ & 0.1 & 0.2 & 0.5 & 1 & 1.8 & 3 \\
\hline Cheese (9 \%) & - & 0.03 & 0.076 & 0.153 & 0.153 & 0.307 \\
\hline «Selyanske dairy butter & - & - & 0.019 & 0.027 & 0.078 & 0.101 \\
\hline Adygeiskiy soft cheese & 0.01 & 0.01 & 0.05 & 0.05 & 0.06 & 0.1 \\
\hline Whey & 0.09 & 0.26 & 0.874 & 1.297 & 1.387 & 2.594 \\
\hline Buttermilk & - & - & 0.051 & 0.073 & 0.208 & 0.27 \\
\hline
\end{tabular}

An analysis of production conditions of milk processing for the conditions of territorial communities in the Brodi- 
vsky region of Lviv oblast (Ukraine) was performed. We used the methodology described above and performed forecasting of daily milk supply for processing by community farms during a calendar year. We used data on volumes of milk supply for processing on individual days of a calendar year presented in [16] for each of 27 communities of the specified administrative district.

Based on the data obtained on the daily volumes of milk supply for processing from individual territorial communities during a calendar year and the above methodology, the volumes of milk processing were forecast during a calendar year at different productivity of milk processing shops. Fig. 2 shows forecasting results.

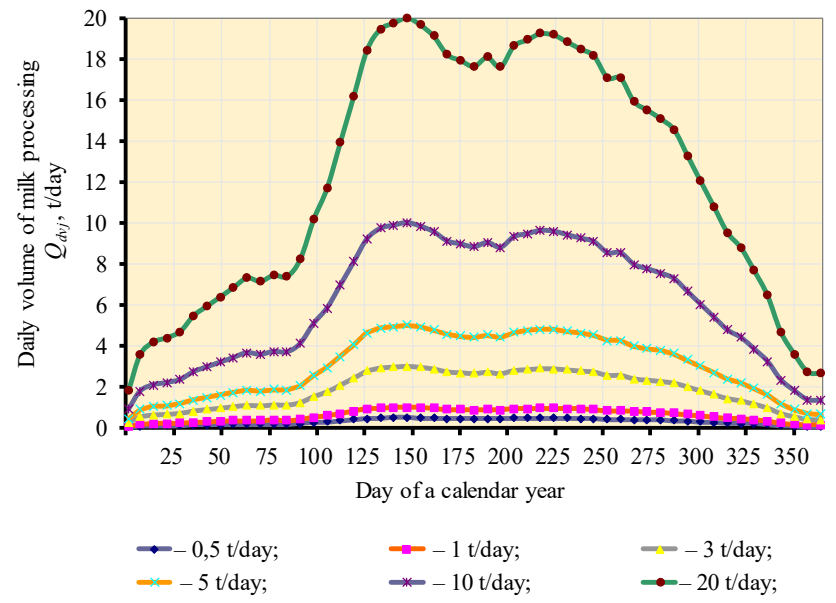

Fig. 2. Forecasted trends of a change in volumes of milk processing during a calendar year at a given productivity of milk processing shops

The results obtained of forecasting of trends in changes in daily volumes of milk processing during a calendar year shows that the volumes are variable. We established that there are two periods of milk supply for processing - an intensive period (from day 119 to day 301 within a calendar year) and non-intensive one (from day 1 to day 118 and from day 302 to day 365 within a calendar year). It is necessary to organize a work of shops in two shifts during the intensive period of milk supply for processing, and one shift - during the non-intensive period of milk supply.

We substantiated distribution of daily milk production on territories of individual communities for each period within a calendar year. It was established that the Weibull distributions laws (Fig. 3, 4) describe distributions of a daily volume of milk production. Table 3 gives their corresponding statistical characteristics.

The main statistical characteristics of distributions of the forecasted daily volume of milk production at the territory of individual communities in Brodisky region of Lviv oblast during the intensive (Fig. 3) and non-intensive (Fig. 4) periods of its supply for processing are, respectively: a coefficient of variation -0.65 and 0.62 ; a shape parameter is 1.56 and 1.64 . The confidence interval is in the range of $509 \ldots 6,995$ and $46 \ldots 6,341$.

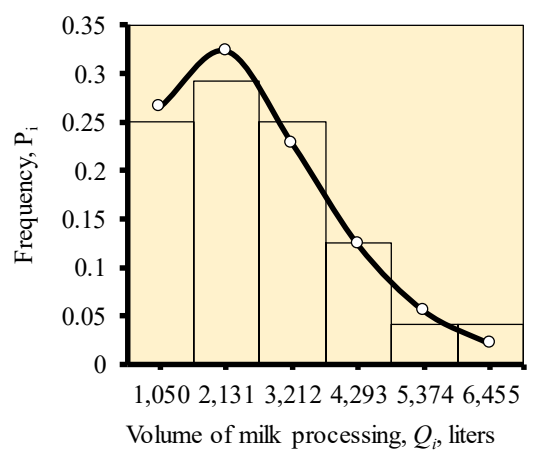

Fig. 3. Distribution of the forecasted

daily volume of milk production in the territory of individual communities during the intensive period of its supply for processing

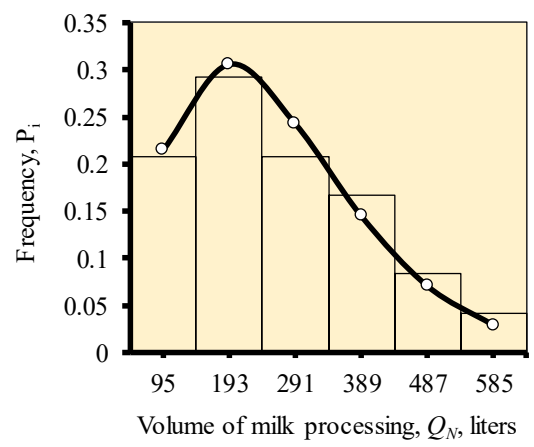

Fig. 4. Distribution of the forecasted

daily volume of milk production in the territory of individual communities during the non-intensive period of its supply for processing

Table 3

Statistical characteristics of distributions of the forecasted daily volume of milk production in the territory of individual communities in separate periods of its supply for processing

\begin{tabular}{|c|c|c|c|}
\hline Indicator & Equations & \multicolumn{2}{|c|}{ Statistical characteristics } \\
\cline { 3 - 4 } & $\bar{\sigma}\left[Q_{i}\right]$ & $\overline{\left.Q_{i}\right]}$ \\
\hline $\begin{array}{c}\text { Intensive period of milk supply for } \\
\text { processing, } 1\end{array}$ & $f\left(Q_{i}\right)=1 \cdot 10^{-3}\left(\frac{Q_{i}-509}{2457}\right)^{0,568} \times \exp \left[-\left(\frac{Q_{i}-509}{2457}\right)^{1,568}\right]$ & 2716 & 266 \\
\hline $\begin{array}{c}\text { Non-intensive period of milk supply for } \\
\text { processing, } 1\end{array}$ & $f\left(Q_{N}\right)=7 \cdot 10^{-3}\left(\frac{Q_{N}-46}{246}\right)^{0,648} \times \exp \left[-\left(\frac{Q_{N}-46}{246}\right)^{1,648}\right]$ & 1429 & 136 \\
\hline
\end{tabular}

Note: $\bar{M}\left[Q_{i}\right], \bar{\sigma}\left[Q_{i}\right]$ are, respectively, a mathematical expectation and a standard deviation of the forecasted daily volume of milk production in the territory of individual communities over the $i$-th period, l; 509, 46 are, respectively, a minimum value of the forecasted volume of daily milk production at the territory of individual communities for intensive and non-intensive periods; 2,457, 246 are, respectively, a scale parameter for intensive and non-intensive periods 
The adequacy of the obtained distributions was checked according to the Pearson criterion $X^{2}$. We calculated its values $X^{2}$ with tabulated ones $\left(X^{*}\right)^{2}$ for the distributions of the forecasted volume of daily milk production in the territory of individual communities during the intensive and non-intensive periods of its supply for processing. Accordingly, the values make up

$$
\begin{aligned}
& \left(X^{2}=0,71\right)<\left(\left(X^{*}\right)^{2}=4,6\right), \\
& \left(X^{2}=0,89\right)<\left(\left(X^{*}\right)^{2}=3,2\right) .
\end{aligned}
$$

Therefore, Weibull's theoretical distribution curves adequately reflect the empirical data of the forecasted daily volume of milk production in the territory of individual communities during the intensive and non-intensive periods of its supply for processing.

Based on the characteristics of "COLAX" modular dairy mini-plants (shops) and the forecasted daily volume of milk production in the territory of individual communities, we performed numerical modeling of the operation of shops using the MS Excel package. The modeling made it possible to obtain functional indicators of the use of modular milk processing shops (Table 4).

Table 4

Functional indicators of the use of modular

\begin{tabular}{|c|c|c|c|c|c|c|}
\hline \multirow[t]{2}{*}{ Characteristics } & \multicolumn{6}{|c|}{$\begin{array}{l}\text { Productivity of a milk } \\
\text { processing shop, } t / \text { day }\end{array}$} \\
\hline & 0.5 & 1 & 3 & 5 & 10 & 20 \\
\hline $\begin{array}{l}\text { Specific con- } \\
\text { sumption of } \\
\text { electricity }\left(\mathrm{P}_{\mathrm{e}}\right) \text {, } \\
\mathrm{kW} / \mathrm{t} \text { of pro- } \\
\text { cessed milk: }\end{array}$ & & & & & & \\
\hline option 1 & 64.0 & 48.0 & 17.3 & 11.4 & 13.9 & 7.8 \\
\hline option 2 & 112.0 & 64.0 & 27.6 & 21 & 24.6 & 16.2 \\
\hline option 3 & 114.0 & 85.0 & 54.3 & 44.4 & 43.9 & 31.9 \\
\hline $\begin{array}{l}\text { Specific con- } \\
\text { sumption }\left(q_{w}\right) \\
\text { of water, } \mathrm{m}^{3} / \mathrm{t} \text { of } \\
\text { processed milk: }\end{array}$ & & & & & & \\
\hline option 1 & 6.0 & 4.0 & 1.3 & 0.8 & 0.4 & 0.3 \\
\hline option 2 & 6.0 & 4.0 & 1.5 & 1.0 & 0.6 & 0.45 \\
\hline option 3 & 10.0 & 6.0 & 2.1 & 1.4 & 0.8 & 1.0 \\
\hline $\begin{array}{l}\text { Specific need } \\
\left(N_{u}\right) \text { for human } \\
\text { labor, persons/t } \\
\text { of processed milk }\end{array}$ & 2.0 & 1.0 & 0.66 & 0.6 & 0.5 & 0.3 \\
\hline
\end{tabular}
milk processing shops

Note: option 1 - production of pasteurized milk; option 2 - production of pasteurized milk and sour cream; option 3 - production of pasteurized milk, sour cream, cultured milk kefir beverage, cheese and butter

We constructed the dependences of functional indicators of using modular milk processing shops on their productivity (Fig. 5-7) based on processing the obtained data given in Table 4. butter butter

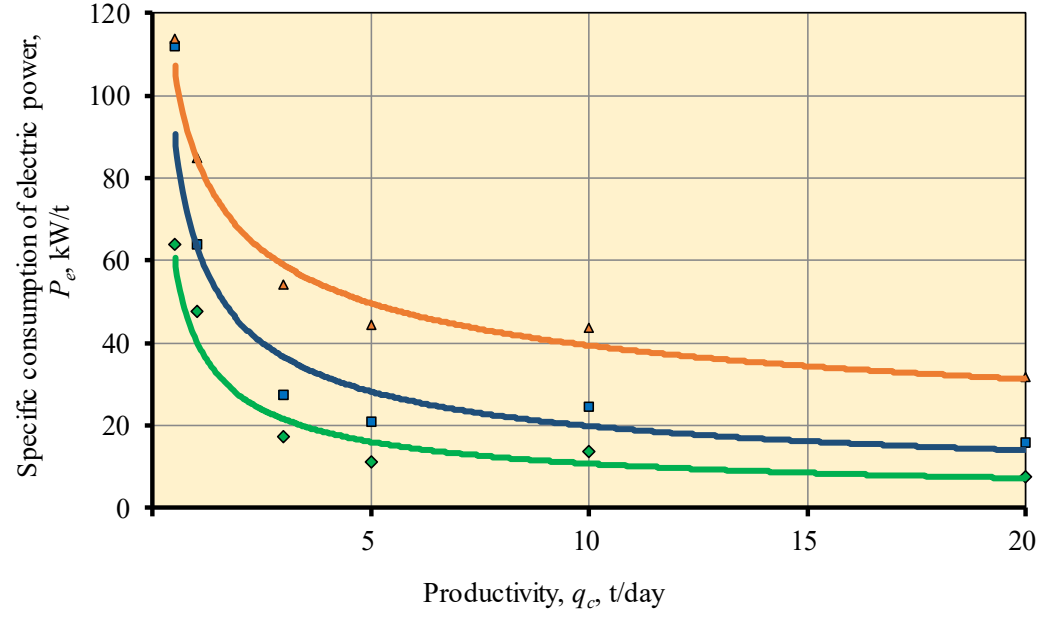

$\diamond$ production of pasteurized milk

- production of pasteurized milk and sour cream

$\Delta$ production of pasteurized milk, sour cream, cultured milk kefir beverage, cheese and

Fig. 5. Dependences of specific consumption $\left(P_{e}\right)$ of electricity on productivity $\left(q_{c}\right)$ of a milk processing shop

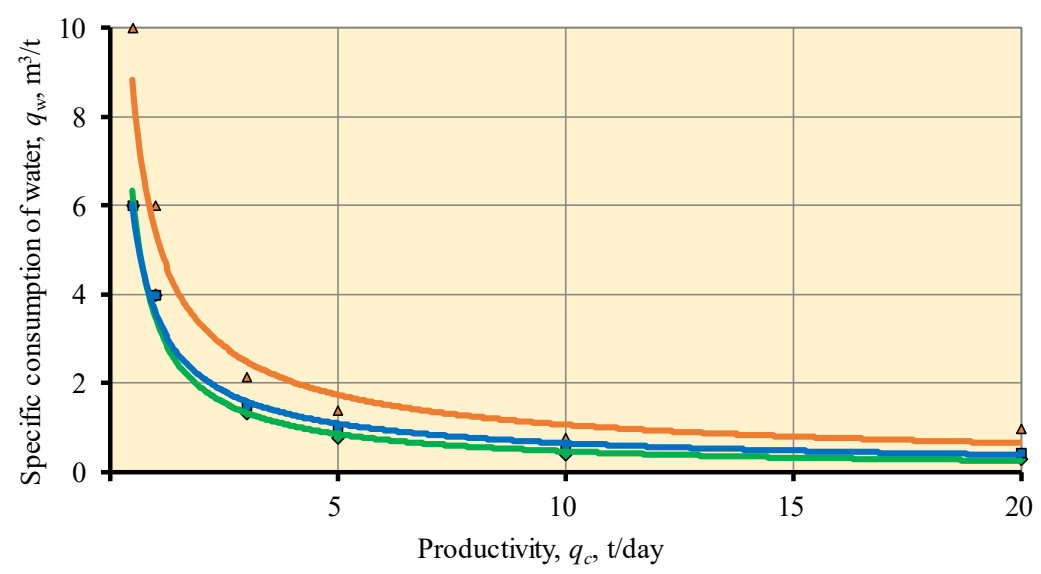

$\diamond$ production of pasteurized milk

a production of pasteurized milk and sour cream

$\Delta$ production of pasteurized milk, sour cream, cultured milk kefir beverage, cheese and

Fig. 6. Dependences of specific consumption $\left(q_{w}\right)$ of water on productivity $\left(q_{c}\right)$ of a milk processing shop

We performed the approximation of the obtained functional indicators of the use of modular milk processing shops (Table 4) using the MS Excel package. The approximation made it possible to define trends in changes in the specific consumption of electricity $\left(P_{e}\right)(\mathrm{kW} / \mathrm{t}$ of processed milk) on the productivity $\left(q_{c}\right)$ of a milk processing shop in production of different types of dairy products (Fig. 5). Exponential lines of trends describe them. The lines have the following equations:

- production of pasteurized milk

$\mathrm{P}_{\mathrm{e}}=40.588 q_{c}^{-0.576}, r=0.92$;

- production of pasteurized milk and sour cream

$\mathrm{P}_{\mathrm{e}}=63.787 q_{c}^{-0.506}, r=0.89$; 
- production of pasteurized milk, sour cream, cultured milk kefir beverage, cheese and butter

$$
\mathrm{P}_{\mathrm{e}}=84.965 q_{c}^{-0.968}, r=0.96 \text {. }
$$

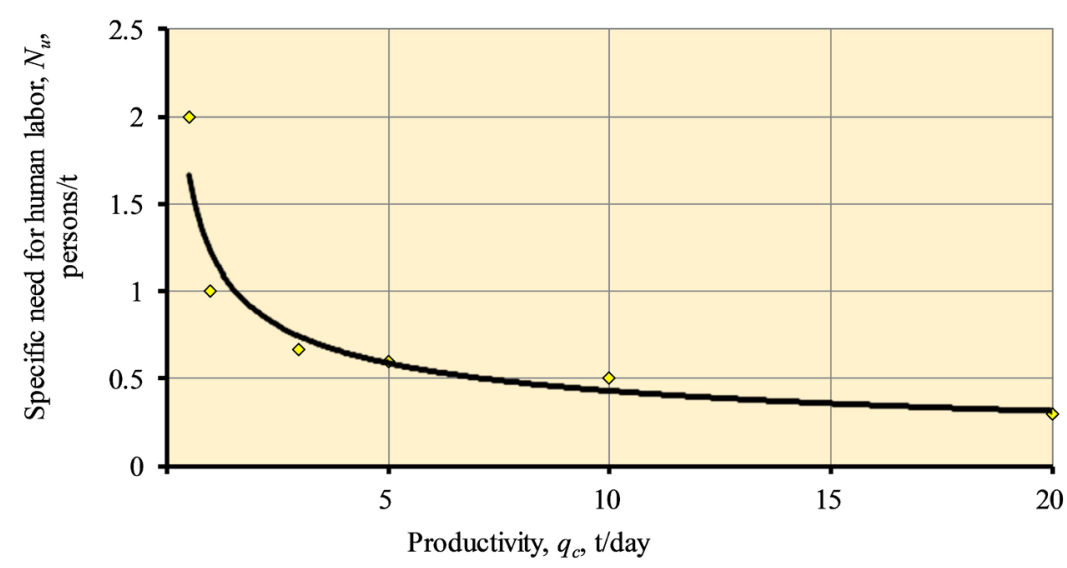

Fig. 7. Dependence of specific need $\left(N_{u}\right)$ for human labor on productivity $\left(q_{c}\right)$ of a milk processing shop

Exponential lines of trends describe trends in changes in the specific consumption of water $\left(q_{w}\right)$ on the productivity $\left(q_{c}\right)$ of a milk processing shop in production of different types of dairy products (Fig. 6). They have the following equations:

- production of pasteurized milk

$q_{w}=3.473 q_{c}^{-0.868}, r=0.99 ;$

- production of pasteurized milk and sour cream

$q_{w}=3.601 q_{c}^{-0.74}, r=0.99$;

- production of pasteurized milk, sour cream, cultured milk kefir beverage, cheese and butter

$$
q_{\varpi}=5.412 q_{c}^{-0.704}, r=0.93 \text {. }
$$

Exponential lines of trends describe trends in changes in the specific need $\left(N_{u}\right)$ in human labor on the productivity $\left(q_{c}\right)$ of a milk processing shop for all options of dairy products production (Fig. 7). The lines correspond to equation:

$$
N_{u}=1.2198 q_{c}^{-0.453}, r=0.94 \text {. }
$$

The obtained dependences show that the increase in the productivity $\left(q_{c}\right)$ of milk processing shops from 0.5 to $20 \mathrm{t} /$ day leads to a proportional decrease in the specific consumption of electricity (Fig. 5) from 116 to $10 \mathrm{~kW} / \mathrm{t}$ of processed milk, the specific consumption of water (Fig. 6) from 10 to $0.3 \mathrm{~m}^{3} / \mathrm{t}$ of processed milk and the specific need $\left(N_{u}\right)$ for human labor (Fig. 7) from 0 to 0.3 persons/t of processed milk in production of different types of dairy products. The correlation between the dependencies is within $0.89 \ldots 0.99$, which indicates a strong relationship between them.

\section{Discussion of results of studying the influence of production conditions on the characteristics of project configuration objects}

The main scientific result is the defined influence of the parameters of community milk processing shops on the indicators of their use taking into account changing production conditions. Studies on the changing production conditions of milk processing at a community territory made it possible to determine existence and duration of two dairy production periods. The periods determine modes of use of processing shops. Experimentally studied tendencies of changes in volumes of milk production volumes in separate communities (Fig. 3, 4) are the initial data for numerical modeling of operation of processing shops at a community territory. They ensure the determination of trends in the changes of indicators of their use at different parameters of the specified shops.

The modeling of processing shops operation at a community territory made it possible to determine indicators of using of processing shops (Fig. 5-7). It was established that the increase in productivity $\left(q_{c}\right)$ of milk processing shops from 0.5 to $20 \mathrm{t} /$ day leads to the proportional decrease in the specific consumption of electricity (Fig. 5) from 116 to $10 \mathrm{~kW} / \mathrm{t}$, specific consumption of water (Fig. 6) from 10 to $0.3 \mathrm{~m}^{3} / \mathrm{t}$ and specific need $\left(N_{u}\right)$ for human labor (Fig. 7) from 0 to 0.3 persons/t in production of different types of dairy products. The correlation ratio between the dependencies is within $0.89 \ldots 0.99$, which indicates a strong relationship between them.

The obtained trends in changes in indicators of functioning of milk processing shops at a community territory (Fig. 2-7) underlie the justification of optimal modes for the use of processing shops. The defined duration of periods of milk supply for processing presented in Fig. 2 made it possible to determine duration of one-shift and two-shift organization of work in a processing shop during a calendar year. It was established that there are two periods of milk processing. The intensive one lasts from day 119 to day 301 within a calendar year, and the non-intensive one has two half-periods - from day 1 to day 118 and from day 302 to day 365 within a calendar year. It is necessary to organize work of shops in two shifts during the intensive period of milk processing, and one shift - in the non-intensive period. The results of the studies are the basis for determination of cost indicators of the use of milk processing shops at a community territory. In addition, the obtained dependences underlie planning of resource expenditures during operation of milk processing shops at the territory of communities.

The substantiated stages and features of forecasting of the functional indicators of milk processing shops at a community territory compose the basis for definition of trends in changes of the mentioned indicators at different parameters of milk processing shops. The proposed approach to forecasting of functional indicators of milk processing shops in the territory of communities eliminates disadvantages of the existing ones due to taking into account changing production conditions of operation of milk processing shops at a community territory and application of numerical modeling of operation of these shops. The obtained results compose a basis for the development of systems for support of decision-making on planning of a configuration of milk processing shops at a community territory. The obtained community statistics 
on milk production and characteristics of milk processing shops form a database for the mentioned decision-making support systems. The established trends of changes in indicators of using of processing shops in the given production conditions provide formation of a knowledge base in the decision-making support system for planning of a configuration of milk processing shops at a community territory.

The proposed approach and the performed studies have some disadvantages. First, the base of the approach is a series of specific experiments for determination of characteristics of production conditions. Second, the approach requires numerical modeling. Quality numerical modeling requires creation of a decision-making support system for planning of a configuration of milk processing shops at a community territory.

The proposed approach and the stages of the study compose a basis for the decision-making support system for planning of a configuration of milk processing shops at a community territory. The system should provide numerical modeling of operation of processing shops at a community territory. This will speed up the process of managerial decision-making for determination of indicators of using of milk processing shops under the given production conditions, and improve their accuracy greatly.

The performed studies are useful for project managers involved in the implementation of projects for creation of milk processing shops at community territories and community leaders, who plan to organize their own dairy production.

\section{Conclusions}

1. The substantiated stages and features of forecasting of functional indicators of milk processing shops at a community territory have five steps. They provide for modeling of functioning of milk processing shops taking into account changing production conditions. They ensure definition of trends in changes in indicators of use of milk processing shops at a community territory at different parameters and taking into account changing production conditions. They also provide formation of a knowledge base for a system of support of management decision-making for planning of a configuration of the mentioned milk processing shops.

2. It was established that the increase in productivity $\left(q_{c}\right)$ of milk processing shops from 0.5 to $20 \mathrm{t}$ /day leads to the proportional decrease in the specific consumption of electricity from 116 to $10 \mathrm{~kW} / \mathrm{t}$ of processed milk, specific consumption of water from 10 to $0.3 \mathrm{~m}^{3} / \mathrm{t}$ of processed milk and specific need $\left(N_{u}\right)$ for human labor from 0 to 0.3 persons/t of processed milk in production of various types of dairy products. The correlation between the dependencies is within $0.89 \ldots 0.99$, which indicates a strong relationship between them. We studied changing production conditions and characteristics of modular milk processing shops available on the market. The identified trends in changes in indicators of their use at a community territory take into account changing production conditions and underlie determination of cost indicators of the use of shops and planning of resource expenditures in projects for creation of milk processing shops at a community territory.

References

1. Tryhuba, A., Boyarchuk, V., Tryhuba, I., Boyarchuk, O., Ftoma, O. (2019). Evaluation of Risk Value of Investors of Projects for the Creation of Crop Protection of Family Dairy Farms. Acta Universitatis Agriculturae et Silviculturae Mendelianae Brunensis, 67 (5), 1357-1367. doi: https://doi.org/10.11118/actaun201967051357

2. Aleksejevs, R., Guseinovs, R., Medvedev, A. N., Guseynov, S. E. (2016). Groupage Cargo Transportation Model. Transport and Telecommunication Journal, 17 (1), 60-72. doi: https://doi.org/10.1515/ttj-2016-0007

3. Liotta, G., Stecca, G., Kaihara, T. (2015). Optimisation of freight flows and sourcing in sustainable production and transportation networks. International Journal of Production Economics, 164, 351-365. doi: https://doi.org/10.1016/j.ijpe.2014.12.016

4. Petraška, A., Čižiūnienė, K., Prentkovskis, O., Jarašūnienė, A. (2018). Methodology of Selection of Heavy and Oversized Freight Transportation System. Transport and Telecommunication Journal, 19 (1), 45-58. doi: https://doi.org/10.2478/ttj2018-0005

5. Bazaras, D., Batarlienè, N., Palšaitis, R., Petraška, A. (2013). Optimal road route selection criteria system for oversize goods transportation. The Baltic Journal of Road and Bridge Engineering, 8 (1), 19-24. doi: https://doi.org/10.3846/bjrbe.2013.03

6. Bula, G. A., Prodhon, C., Gonzalez, F. A., Afsar, H. M., Velasco, N. (2017). Variable neighborhood search to solve the vehicle routing problem for hazardous materials transportation. Journal of Hazardous Materials, 324, 472-480. doi: https://doi.org/10.1016/ j.jhazmat.2016.11.015

7. Doumiati, M., Erhart, S., Martinez, J., Sename, O., Dugard, L. (2014). Adaptive control scheme for road profile estimation: application to vehicle dynamics. IFAC Proceedings Volumes, 47 (3), 8445-8450. doi: https://doi.org/10.3182/20140824-6za-1003.00986

8. Gardziejczyk, W., Zabicki, P. (2017). Normalization and variant assessment methods in selection of road alignment variants - case study. Journal of civil engineering and management, 23 (4), 510-523. doi: https://doi.org/10.3846/13923730.2016.1210223

9. Tryhuba, A., Ftoma, O., Tryhuba, I., Boyarchuk, O. (2019). Method of quantitative evaluation of the risk of benefits for investors of fodder-producing cooperatives. 14th International Scientific and Technical Conference on Computer Sciences and Information Technologies (CSIT), 55-58.

10. Ratushny, R., Tryhuba, A., Bashynsky, O., Ptashnyk, V. (2019). Development and Usage of a Computer Model of Evaluating the Scenarios of Projects for the Creation of Fire Fighting Systems of Rural Communities. 2019 XIth International Scientific and Practical Conference on Electronics and Information Technologies (ELIT). doi: https://doi.org/10.1109/elit.2019.8892320

11. Andrés, L., Padilla, E. (2015). Energy intensity in road freight transport of heavy goods vehicles in Spain. Energy Policy, 85, 309321. doi: https://doi.org/10.1016/j.enpol.2015.06.018 
12. Ratushnyi, R., Khmel, P., Tryhuba, A., Martyn, E., Prydatko, O. (2019). Substantiating the effectiveness of projects for the construction of dual systems of fire suppression. Eastern-European Journal of Enterprise Technologies, 4 (3 (100)), 46-53. doi: https://doi.org/10.15587/1729-4061.2019.175275

13. Tryhuba, A., Pavlikha, N., Rudynets, M., Tryhuba, I., Grabovets, V., Skalyga, M. et. al. (2019). Studying the influence of production conditions on the content of operations in logistic systems of milk collection. Eastern-European Journal of Enterprise Technologies, 3 (3 (99)), 50-63. doi: https://doi.org/10.15587/1729-4061.2019.171052

14. Benekos, I., Diamantidis, D. (2017). On risk assessment and risk acceptance of dangerous goods transportation through road tunnels in Greece. Safety Science, 91, 1-10. doi: https://doi.org/10.1016/j.ssci.2016.07.013

15. Newnam, S., Goode, N., Salmon, P., Stevenson, M. (2017). Reforming the road freight transportation system using systems thinking: An investigation of Coronial inquests in Australia. Accident Analysis \& Prevention, 101, 28-36. doi: https://doi.org/10.1016/ j.aap.2017.01.016

16. Tryhuba, A., Zachko, O., Grabovets, V., Berladyn, O., Pavlova, I., Rudynets, M. (2018). Examining the effect of production conditions at territorial logistic systems of milk harvesting on the parameters of a fleet of specialized road tanks. Eastern-European Journal of Enterprise Technologies, 5 (3 (95)), 59-70. doi: https://doi.org/10.15587/1729-4061.2018.142227

17. Park, S.-W. (2004). Modeling of deformational characteristics in unbound granular geomaterials. KSCE Journal of Civil Engineering, 8 (3), 281-285. doi: https://doi.org/10.1007/bf02836010

18. Pauer, G. (2017). Development Potentials and Strategic Objectives of Intelligent Transport Systems Improving Road Safety. Transport and Telecommunication Journal, 18 (1), 15-24. doi: https://doi.org/10.1515/ttj-2017-0002

19. Petraška, A., Čižiūnienė, K., Jarašūnienė, A., Maruschak, P., Prentkovskis, O. (2017). Algorithm for the assessment of heavyweight and oversize cargo transportation routes. Journal of Business Economics and Management, 18 (6), 1098-1114. doi: https://doi.org/ 10.3846/16111699.2017.1334229

20. Tryhuba, A., Bashynsky, O. (2019). Coordination of dairy workshops projects on the community territory and their project environment. 14th International Scientific and Technical Conference on Computer Sciences and Information Technologies (CSIT), 51-54.

21. Bartuška, L., Biba, V., Jeřábek, K. (2016). Verification of Methodical Procedure for Determining the Traffic Volumes Using Shortterm Traffic Surveys. Procedia Engineering, 161, 275-281. doi: https://doi.org/10.1016/j.proeng.2016.08.553

22. Maitah, M., Hodrab, R., Malec, K., Shanab, S. A. (2015). Exploring the Determinants of Consumer Behavior in West Bank, Towards Domestic and Imported Dairy Products. Acta Universitatis Agriculturae et Silviculturae Mendelianae Brunensis, 63 (1), 355-368. doi: https://doi.org/10.11118/actaun201563010355

23. Barłowska, J., Litwińczuk, Z., Kowal, M. (2014). Influence of Production Season and Lactation Stage on the Technological Suitability of Milk from Cows of Various Breeds Fed in the TMR System. Annals of Animal Science, 14 (3), 649-661. doi: https://doi.org/ 10.2478/aoas-2014-0039

24. Bandyopadhyay, P., Khamrui, K. (2007). Technological advancement on traditional indian desiccated and heat-acid coagulated dairy products. Australian Journal of Dairy Technology, 62 (2), 4-10. 